\title{
PENGARUH VARIASI JUMLAH TEMBAKAN NANOSECOND PULSED ELECTRIC FIELDS (NSPEFS) TERHADAP EKSPRESI GEN SOCS3 PADA SEL KANKER SERVIKS HELA S3
}

\author{
EFFECT OF VARIATIONS OF NANOSECOND PULSED ELECTRIC FIELDS \\ (NSPEFS) SHEETS ON GEN SOCS3 EXPRESSION ON HELA S3 SERVICAL \\ CANCER CELL
}

\author{
Martina Kurnia Rohmah \\ STIKes RS Anwar Medika \\ Jl. Bypass Krian KM.33, Balongbendo, Balong Bendo, Kabupaten Sidoarjo, Jawa Timur 61263 \\ email: martina.kurniarohmah@gmail.com
}

\section{Histori Artikel: \\ Submitted: \\ $18 / 08 / 2017$ \\ Revised: \\ 08/09/2017}

Accepted:

22/09/2017

\section{ABSTRAK}

Nanosecond Pulsed Electric Fields (NsPEFs) merupakan teknologi bioelektrik yang berkembang dari teknologi elektroporasi. NsPEFs diberikan dengan intensitas tinggi namun dalam waktu yang sangat singkat yaitu 1 - 300 nanosekon. NsPEFs terbukti memiliki sejumlah efek biologis dan telah banyak dikembangkan dalam berbagai terapi salah satunya pada terapi kanker. Pada kanker serviks, protein HPV dapat menekan sejumlah ekspresi supresor tumor salah satunya yaitu gen Socs3. Penelitian ini bertujuan untuk mengetahui pengaruh perbedaan jumlah tembakan NsPEFs pada ekspresi gen Socs3. Sel HeLa S3 dikultur pada medium $\alpha$-MEM dengan serum FBS $10 \%$. Sebesar $20 \mathrm{kV} / \mathrm{cm}$ dalam durasi 80 ns NsPEFs dipapar pada suspensi sel dalam $4 \mathrm{~mm}$ cuvette. Gelombang NsPEFs dideteksi oleh probe bervoltase tinggi pada Oscilloscope. NsPEFs diberikan pada $0,5,10,20,30,40,0$, dan 60 kali tembakan. Analisis ekspresi gen dilakukan dengan dua metode yaitu kuantitatif menggunakan Real time PCR dan kualitatif dengan RT-PCR. Data kuantitatif dianalisis secara statistik menggunakan Kolmogorf-Smirnov, Anova dan HSD Tukey $(\mathrm{p}<0.05)$. Hasil studi ini membuktikan bahwa paparan NsPEFs berpengaruh secara signifikan pada ekspresi gen Socs3 ( $\mathrm{p}=0.000)$. Jumlah tembakan optimal 20 dan 30 kali dapat meningkatkan ekspresi gen Socs3 berturut-turut sebanyak $\bar{X}=2.779$ dan $\bar{X}=3.105$ kali. Ekspresi gen Socs3 akan menurun pada tembakan di atas 30 tembakan.

Kata Kunci: NsPEFs, tembakan, ekspresi, Socs3

\begin{abstract}
Nanosecond Pulsed Electric Fields (NsPEFs) is bioelectric that was developed by electroporation technology. NsPEFs use high intensity in short time exposure (1 - 300 nanosecond). NsPEFs have biological effect and was developed in cancer therapy. In cervical cancer, viral protein of HPV depresses some tumor suppressors like Socs3 gene. This research aims to investigate the effect of short variation in Socs3 gene expression. HeLa S3 cells were cultured in $\alpha$-MEM with FBS 10\%. NsPEFs as much as 20 $\mathrm{kV} / \mathrm{cm}$ and 80 nano seconds was exposure over HeLa S3 cell in $4 \mathrm{~mm}$ cuvette. Wave of NsPEFs was detected by high voltage probe in oscilloscope. NsPEFs was exposure at 0 (control), 5, 10, 20, 30, 40, 50, and 60 shots. Socs3 gene expression was analyzed using real time PCR and RT-PCR. Quantitative data was analyzed by Kolmogorov-Smirnov, Anova, and HSD Tuker $(\mathrm{p}<0.05)$. This research show that NsPEFs is significantly increase Socs 3 gene expression $(\mathrm{p}=0.000)$. The optimal shot 20 and 30 shots increase Socs3 gene expression subsequently $\bar{X}=2.779$ and $\bar{X}=3.105$ times. This expression decrease in higher than 30 shots of NsPEFs exposure.
\end{abstract}

Keywords: NsPEFs, shot, expression, Socs3 


\section{PENDAHULUAN}

Nanosecond Pulsed Electric Fields (NsPEFs) merupakan salah satu aplikasi teknologi bioelektris yang dikembangkan dari teknik elektroporasi. Elektroporasi banyak digunakan secara luas di bidang biologi dan kedokteran misalnya untuk menyampaikan plasmid, gen, antibodi ataupun molekul lain ke dalam sel dengan berbagai tujuan salah satunya adalah untuk terapi (Chen et al., 2006). Teknologi baru ini memperbaiki kelemahan dan efek samping dari elektroporasi dalam hal terapi pada sel. NsPEFs dipaparkan dalam waktu yang sangat singkat yaitu 1 - 300 nanosekon dengan intensitas listrik yang besar yaitu 10 - 100 $\mathrm{kV} / \mathrm{cm}$ (Beebe dan Schoenbach, 2005). Dengan karakter ini, NsPEFs memiliki densitas energi kecil sehingga tidak menimbulkan efek termal yang menyebabkan kerusakan pada sel target. Namun demikian, NsPEFs akan membentuk porus yang kecil pada membran sel sehingga akan mudah dilewati oleh molekul kecil seperti plasmid, gen, antibodi dan senyawa kimia tanpa mengganggu integritas dari sel tersebut (Beebe et al., 2012).

Pada sejumlah sel kanker, NsPEFs terbukti memiliki aktivitas penghambatan pada penurunan viabilitas sel kanker (Stacey et al., 2003), penurunan proliferasi (Beebe et al., 2002; Ren et al., 2013), menurunkan masa tumor (Nagahama et al., 2013), serta dapat menginduksi apoptosis (Nuccitelli et al., 2009; Beebe et al., 2013; Ren dan Beebe, 2011; Zou et al., 2013). Pada tingkat keganasan yang lebih tinggi, NsPEFs mampu menurunkan kemampuan invasi dan metastasis sel kanker melalui penurunan ekspresi VEGF dan MMP (Ren et al., 2013; Wu et al., 2014).

Kanker serviks merupakan salah satu kanker ginekologis yang disebabkan oleh infeksi virus HPV. Dua protein virus utama HPV yaitu E6 dan E7 merupakan protein yang bertanggungjawab pada proses karsinogenesis dan instabilitas genetik sel serviks (Burd et al., 2003). Kehadiran genom HPV diasosiasikan dengan overekspresi STAT3 dan STAT yang berimplikasi pada prognosivitas kanker (Sobti et al., 2009; Sobti et al., 2010). Peningkatan ekspresi STAT3 dan 5 berkaitan juga dengan hilangnya kontrol epigenetik yang menyebabkan metilasi pada sejumlah supresor tumor salah satunya gen Socs3 (Webces et al., 2014). Penelitian ini bertujuan untuk mengetahui pengaruh variasi jumlah tembakan NsPEFs pada ekspresi gen socs3 pada sel kanker HeLa S3.

\section{METODE PENELITAN}

\section{A. Kultur Sel dan Preparasi Sampel}

Sel HeLa S3 (ATCC) sebanyak 2 x $10^{6} \mathrm{sel} / \mathrm{ml}$ dikultur pada medium $\alpha$-minimum essential medium ( $\alpha$-MEM) (WAKO) dengan serum FBS $10 \%$ dan penicillin/streptomycin (WAKO) pada suspense $400 \mu \mathrm{l}$. Sel dikultur pada inkubator $\mathrm{CO}_{2} 5 \%$ pada suhu $37^{\circ} \mathrm{C}$. Sel dihitung menggunakan cell counter coulter Z.1. Primer yang digunakan untuk mengamplifikasi gen didapatkan dengan optimasi primer antara lain socs3 (107 bp), F: 5' $^{\prime}$ TCCCCCCAGAAGAGCCTATTAC-3'; R: 5'TCCGACAGAGATGCTGAAGAGTG-3'; GAPDH (452 bp), F: 5'-ACCACAGTCCATGCCATCAC-3', R: 5'-TCCACCACCCTGTTGCTGTA-3'.

Optimasi dilakukan berdasarkan pada ada tidaknya primer dimer yang ditunjukkan oleh puncak tertinggi pada kurva denaturasi.

\section{B. Aplikasi NsPEFs}

Suspensi sel HeLa S3 dimasukkan ke dalam kuvet pada suatu eletroda aluminium paralel dengan jarak $4 \mathrm{~mm}$ (\#5540, M $\beta$ P, Thermo Fisher Scientific). NsPEFs terbentuk oleh adanya pulsed power modulator. Voltase gelombang NsPEFs yang dihasilkan dideteksi oleh probe bervoltase tinggi (P6015A, Textronix) pada Oscilloscope. Aplikasi NsPEFs dilakukan dengan 7 variasi tembakan yaitu 5 , 10, 20, 30, 40, 50, 60 shot. NsPEFs diberikan pada frekuensi $1 \mathrm{Hx}$ dengan kondisi maksimum $20 \mathrm{kV} / \mathrm{cm}$ atau $8 \mathrm{kV}$ dalam durasi $80 \mathrm{nsec}$ setiap tembakan (Morotomi-Yano et al., 2011).

\section{Isolasi RNA}

RNA total diisolasi dari semua sampel menggunakan reagen RNAiso Plus (Takara Bio). Konsentrasi dan kemurnian RNA akan dikonfirmasi menggunakan Biophotometer plus (Eppendorf). Berdasarkan hasil optimasi kualitas sampel RNA, maka panjang gelombang yang digunakan untuk mengukur konsentrasi isolat RNA yaitu 260/280 dengan nilai OD (optical density) sebesar 1.8 - 2.0. Isolasi RNA dilakukan berdasarkan protocol TAKARA BIO INC. Cat \#9108/9109 V0803Da). Konsetrasi RNA total ditentukan dengan rumus:

Konsentrasi RNA $=\mathrm{OD}_{260 / 280} \mathrm{x}$ pengenceran $(100)$ $\mathrm{x} 0.04$

\section{Analisis Real Time PCR}

Real Time PCR digunakan untuk mengetahui ekspresi gen Socs3 melalui metode kuantitatif. Kuantitatif real time PCR yang digunakan yaitu iSripct One-Step RT PCR kit dengan SYBR green 


\section{Martina Kurnia Rohmah}

Pengaruh Variasi Jumlah Tembakan Nanosecond Pulsed Electric FIELDS (NsPEFs) Terhadap Ekspresi Gen Socs3 pada Sel Kanker Serviks Hela S3

(Biorad) pada MJ Mini Thermal Cycler dengan Mini Opticon Real Time PCR system (Biorad) dalam 45 siklus. Data real time PCR dikalkulasi dengan mengukur rata-rata nilai Cycle Threshold (CT) pada gen target dengan menggunakan Glyceraldehydes -3- Phosphate Dehydrogenase (GAPDH) sebagai kontrol.

\section{E. Analisis Reverse Transcriptase PCR (RT- PCR)}

Reverse Transciptase PCR merupakan pengukurun mRNA secara semikuantitatif. Kit RT-PCR yang digunakan yaitu OneStep RT-PCR (Qiagen) pad RT-PCR system. Kondisi RT-PCR yang digunakan yaitu: 1) transkripsi balik (30 menit $\left.45^{\circ} \mathrm{C}\right), 2$ ) aktivasi PCR (15 menit $\left.95^{\circ} \mathrm{C}\right), 3$ ) denaturation (10 detik $\left.\left.94^{\circ} \mathrm{C}\right), 4\right)$ annealing (1 menit $\left.50-68^{\circ} \mathrm{C}\right), 5$ ) extension ( 1 menit $\left.68^{\circ} \mathrm{C}\right), 6$ ) reaksi perpanjangan akhir $\left(10\right.$ menit $\left.68^{\circ} \mathrm{C}\right)(45$ siklus). Produk PCR dipisahkan pada jel agarose dan divisualisasikan menggunakan UV transluminator. Intensitas band akan dikuantitatifkan menggunakan software imageJ.

\section{F. Analisis Statistik}

Data dipresentasikan dengan jumlah rerata dan nilai standar deviasi, Distribusi data dievaluasi menggunakan analisis KolmogorovSmirnov. Data dianalisis menggunakan ANOVA dengan HSD Tukey sebagai studi lanjut menggunkan taraf signifikansi $0<0.05$. Penggolahan data statistik menggunakan SPSS 23.

\section{HASIL DAN PEMBAHASAN}

\section{A. Hasil Analisis Ekspresi Gen Menggunakan Real Time PCR}

Ekspresi gen Socs3 hasil amplifikasi menggunakan real time PCR direpresentasikan dengan nilai Cycle Threshold (CT). Berdasarkan hasil uji normalitas menggunakan KolmogorovSmirnov diketahuai bahwa data nilai ekspresi gen SOCS3 terdistribusi normal $(\mathrm{p}=0.200)$. Berdasarkan uji Anova diketahui bahwa jumlah tembakan NsPEFs signifikan terhadap ekspresi gen $(p=0.000)$. Adapun hasil uji lanjut HSD Tukey diketahui bahwa semua jumlah tembakan NsPEFs berbeda signifikan dengan kontrol (0 tembakan) yang ditunjukkan dengan perbedaan notasi. Tabel 1 merupakan data mean dan standar deviasi serta hasil uji Anova dengan HSD Turkey.
Tabel 1 Tabel Analisis Pengaruh Tembakan NsPEFs pada Ekspresi Gen Socs3 Hasil Uji Real Time PCR

\begin{tabular}{|c|l|c|}
\hline No. & \multicolumn{1}{|c|}{ Perlakuan } & Mean \pm SD \\
\hline 1 & 0 tembakan (Kontrol) & $1 \pm 0^{\mathrm{a}}$ \\
\hline 2 & 60 tembakan & $1.238 \pm 0.012^{\mathrm{b}}$ \\
\hline 3 & 50 tembakan & $1.898 \pm 0.022^{\mathrm{c}}$ \\
\hline 4 & 5 tembakan & $\begin{array}{c}1.998 \pm 0.075 \\
\text { cd }\end{array}$ \\
\hline 5 & 40 tembakan & $2.109 \pm 0.08^{\mathrm{de}}$ \\
\hline 6 & 10 tembakan & $2.223 \pm 0.144^{\mathrm{e}}$ \\
\hline 7 & 20 tembakan & $2.779 \pm 0.051^{\mathrm{f}}$ \\
\hline 8 & 30 tembakan & $3.105 \pm 0.068 \mathrm{~g}$ \\
\hline
\end{tabular}

Catatan: Notasi yang berbeda menunjukkan perbedaan pengaruh yang signifikan

Adapun grafik analisis pengaruh tembakan NsPEFs terhadap ekspresi gen Socs3 ditunjukkan pada Gambar 1.

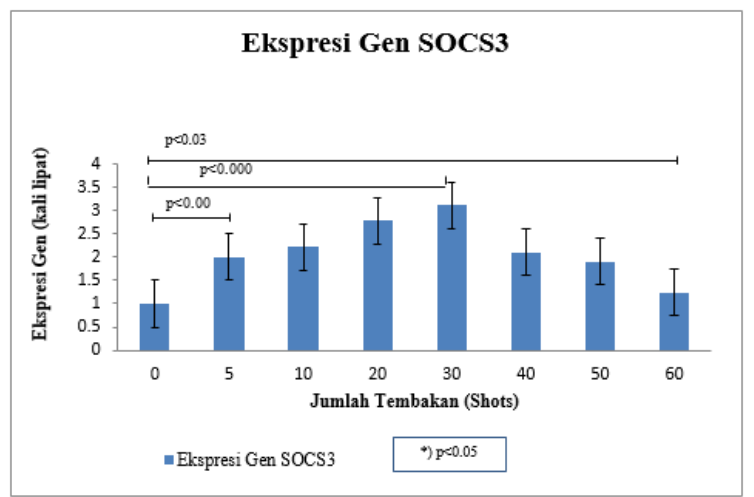

\section{Gambar 1 Grafik Analisis Pengaruh Tembakan NsPEFs terhadap Ekspresi Gen Socs3}

Selain menggunakan analisis kuantitatif dengan real time PCR, analisis ekspresi gen Socs3 juga dilihat dari hasil analisis kualitatif menggunakan RT-PCR. Adapun hasil analisis RT-PCR ditunjukkan pada Gambar 2.

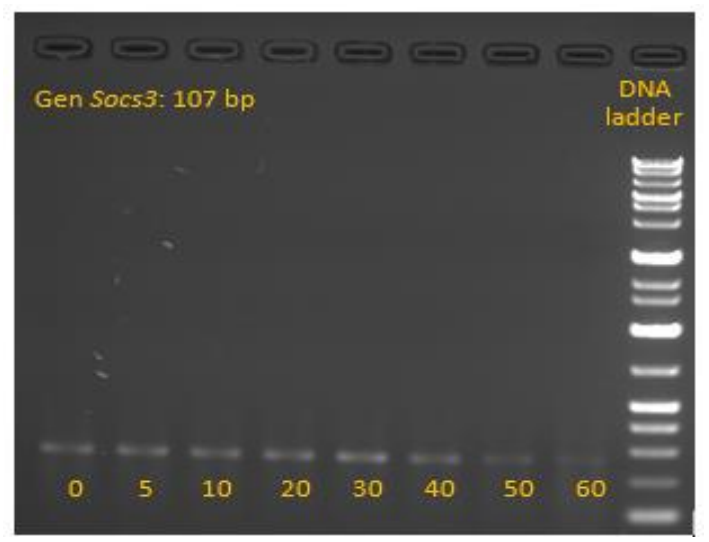

Gambar 2 Ekspresi pita DNA dari gen Socs3 dari Hasil Analisis RT-PCR yang divisualisasikan Hasil Elektroforesis 


\section{Martina Kurnia Rohmah}

Pengaruh Variasi Jumlah Tembakan Nanosecond Pulsed Electric FIELDS (NsPEFs) Terhadap Ekspresi Gen Socs3 pada Sel Kanker Serviks Hela S3

\section{Melalui Pembacaan dengan UV Transluminator.}

Berdasarkan hasil analisis data diketahui bahwa pemberian tembakan NsPEFs memiliki pengaruh yang signifikan dalam meningkatkan ekspresi gen Socs3 terbukti dari nilai Ct yang lebih tinggi dibandingkan kontrol. Pada Gambar 1 tampak bahwa ekspresi gen Socs3 tertinggi dihasilkan dari pemberian tembakan NsPEFs sebesar 30 tembakan yang berbeda signifikan dengan tembakan NsPEFs lainnya $(p=0.000)$. Pemberian NsPEFs sebesar 30 tembakan dapat meningkatkan ekspresi gen Socs3 sebesar $\bar{X}=$ 3.105 kali lipat dibanding kontrol. Ekspresi gen Socs3 tertinggi kedua dihasilkan dari perlakuan tembakan NsPEFs sebesar 20 tembakan dan berbeda signifikan dengan tembakan yang lain. Pemberian NsPEFs sebesar 20 tembakan dapat meningkatkan ekspresi gen Socs3 sebesar $\bar{X}=$ 2.779 kali. Pemberian NsPEFs selanjutnya yang dapat meningkatkan ekspresi gen Socs3 setelah 30 dan 20 tembakan berturut-turut yaitu 10 , $40,5,50$, dan 60 namun tidak berbeda signifikan. Jika dianalisa maka jumlah tembakan NsPEFs yang optimal untuk meningkatkan ekspresi gen Socs 3 yaitu pada 30 tembakan. Hasil analisis menggunakan real time PCR (kuantitatif) ini tidak berbeda dengan hasil RT-PCR (kualitatif) yang ditunjukkan pada Gambar 2. Pada Gambar 2 menunjukkan bahwa tembakan NsPEFs sebesar 30 tembakan memberikan hasil ekspresi gen Socs3 tertinggi dibandingkan pada jumlah tembakan lainnya.

Meninjau kembali grafik ekspresi gen Socs3 pada Gambar 1 dan pita DNA gen Socs3 pada Gambar 2, maka tren jumlah tembakan pemberian NsPEFs dari 5 sampai 60 tembakan yaitu meningkat dari 5, 10, 20 lalu mencapai puncak ekspresinya pada 30 tembakan. Setelah 30 tembakan, ekspresi gen Socs3 akan menurun pada 40, 50 dan 60 tembakan, namun masih di atas ekspresi pada perlakuan kontrol. Hal ini menunjukkan bahwa tembakan NsPEFs memiliki nilai yang optimal untuk dapat meningkatkan ekspresi gen Socs3.

\section{B. PEMBAHASAN}

Pada sejumlah kanker, terjadi silencing sejumlah supresor tumor dapat mengakibatkan prognosivitas kanker. Protein virus E6 dan E7 dari Human Pappiloma Virus (HPV) terbukti dapat mendegradasi supresor tumor p53 yang menurunkan kemampuan apoptosis, sedangkan E7 dapat mengikat pRb, p107, dan p103 sehingga merusak ikatan kompleks pRb dan E2F yang dapat meningkatkan kemampuan proliferasi kanker serviks (Burd, 2003). Kehadiran genom HPV diasosiasikan dengan overekspresi STAT3 dan STAT yang berimplikasi pada prognosivitas kanker (Sobti et al., 2009; Sobti et al., 2010). Peningkatan ekspresi STAT3 dan 5 berkaitan juga dengan hilangnya kontrol epigenetik yang menyebabkan metilasi pada sejumlah supresor tumor salah satunya gen Socs3 (Webces et al., 2014). Protein virus HPV juga terbukti dapat menyebabkan metilasi pada gen Socs1 dan Socs3 (Sobti et al., 2009; Sobti et al., 2010; Wences et al., 2014). Metilasi ini berkaitan dengan peningkatan ekspresi faktor transkripsi STAT1, 3 dan 5. Metilasi menyebabkan gen socs1 dan socs3 mengalami silencing sehingga dapat menyebabkan peningkatan proliferasi dan penurunan apoptosis pada jalur JAK/STAT (Singh et al., 2011). Mekanisme socs1 dan socs3 sebagai tumor supresor yaitu dengan menurunkan ekspresi $c$-myc dan ekspresi bcl-xl sehingga dapat meningkatkan proliferasi dan menurunkan apoptosis (Martin et al., 2007). Sehingga peningkatan ekspresi socs3 sangat penting untuk mengembalikan kondisi internal sel kanker serviks dalam proses perbaikan seluler.

Berdasarkan hasil penelitian terdahulu diketahui bahwa NsPEFs terbukti dapat menimbulkan efek biologis pada sel (Beebe dan Schoenbach, 2005), mengaktifkan sejumlah jalur sinyal melalui mobilisasi $\mathrm{Ca}^{2+}$ (MorotomiYano et al., 2012), mengaktifkan jalur sinyal MAPK (Morotomi-Yano et al., 2011), dan sejumlah penekanan ekspresi gen pada sejumlah jalur sinyal yang berimplikasi pada penurunan proliferasi sel, peningkatan apoptosis, penurunan invasi dan metastasis (Ren et al., 2013). Penelitian ini merupakan studi untuk mengivestigasi adanya pengaruh jumlah tembakan NsPEFs pada ekspresi gen socs3 yang mengalami penurunan ekspresi dan silencing pada kanker serviks.

Berdasarkan hasil penelitian ini diketahui bahwa NsPEFs memberikan pengaruh yang signifikan dalam meningkatkan ekspresi gen Socs3. Dari hasil analisis data juga diketahui bahwa jumlah tembakan yang optimal untuk meningkatkan ekspresi gen socs3 yaitu pada tembakan 20 dan yang tertinggi adalah 30 tembakan. Dengan mempelajari tren ekspresi gen Socs3 dari seluruh tembakan terjadi peningkatan ekspresi Socs3 mulai dari 5 
tembakan hingga 30 tembakan dan akan mengalami penurunan pada 40 sampai 60 tembakan. Pada penelitian sebelumnya diketahui bahwa NsPEFs mampu menginduksi ekspresi gen socs1 dan socs3 namun bukan socs2 (Rohmah et al., 2015). Hal ini mengindikasikan bahwa mekanisme peningkatan ekspresi gen Socs3 tidak melalui jalur sinyal JAK/STAT. Induksi dan peningkatan ekspresi gen Socs3 kemungkinan melalui proses demetilasi dikarenakan NsPEFs terbukti dapat menimbulkan efek fisik yang pada akhirnya dapat menimbulkan efek biologis yaitu degradasi polimerasi dan gugus metil pada gen socs3.

Adanya jumlah tembakan yang optimal untuk meningkatkan ekspresi gen Socs3 yaitu pada tembakan 20 dan 30 kali sesuai dengan teori bahwa perbedaan jumlah tembakan NsPEFs berkaitan dengan perbedaan kondisi seluler berupa viabilitas sel (Morotomi-Yano et al., 2011) dan sejumlah ekspresi gen (Morotomi-Yano et al., 2011; Morotomi-Yano et al., 2012). Perbedaan jumlah tembakan mengindikasikan perbedaan yang ditimbulkan oleh NsPEFS pada sel. NsPEFs akan membentuk

\section{DAFTAR PUSTAKA}

Beebe, S.J., Fox, P.M., Rec, L.J., Somers, K., Stark, R.H., Schoenbach, K.H. 2002. IEEE. Transact. Plasm. Sci. 30: 286-291.

Beebe, S.J., and Schoenbach, K.H. 2005. Nanosecond Pulsed Electric Fields: A New Stimulus to Activate Intracellular Signaling. J. Biomed. Biotech. 4: 297-300.

Beebe, S.J., Chen, Y.J., Sain, N.M., Schoenbach, K.H., Xiao, S. 2012. Transient Feature in Nanosecond Pulsed Electric Fields Differentially Modulate Mitochondria and Viability. PloS One. 7.

Beebe, S.J. 2013. Bioelectrics in Basic Science and Medicine: Impact of Electric Fields on Cellular Structures and Functions. Nanomed. and Nanotech. 4: 1-8.

Burd EM. Human Papillomavirus and Cervical Cancer. Clinical of Microbiology Review. 2003; 16(1): 1-17.

Chen C, Smye SW, Robinson MP, and Evan JA. 2006. Membrane Electroporation Theories: A Review. Medical \& Biological Engineering \& Computing. 44(1-2): 5-14.

Deng, J., Schoenbach, K.H., Buescher, E.S., Hair, P., Fox, P.M., Beebe, S.J. 2003. The Effect of Intense Submicrosecond Electrical Pulses on cells. Biophys. J. 84: 2709-2714. porus yang kecil pada membrane sel namun dapat menutup kembali secara cepat sehingga tidak mengganggu integritas membrane (Deng et al., 2003). Ketika satu tembakan diberikan akan mempengaruhi pembentukan porus pada membran dan mengaktifkan sejumlah efek biologi di dalam sel. Kami berasumsi bahwa tembakan 5-30 kali akan membentuk porus yang semakin besar. Porus yang dihasilkan dari tembakan 30 kali merupakan tembakan yang optimal memasukkan material fisik NsPEFs dan mempengaruhi aktivitas seluler dan meningkatkan ekspresi gen socs3. Namun tembakan di atas 30 kali justru akan merusak molekul secara fisik salah satunya dengan penurunan ekspresi gen Socs3.

\section{KESIMPULAN}

Paparan NsPEFs berpengaruh secara signifikan pada ekspresi gen Socs3. Tembakan yang optimal yaitu 20 dan 30 kali dapat meningkatkan ekspresi gen Socs3 berturutturut sebanyak $\bar{X}=2.779$ dan $\bar{X}=3.105$ kali. Ekspresi gen Socs3 akan menurun pada tembakan di atas 30 tembakan.

ఏimenez-Wences $\mathrm{H}$, Peralta-Zaragoza $\mathrm{O}$, and Fernández-Tilapa G. 2014. Human Papilloma Virus, DNA Methylation and micoRNA in Cervical Cancer. Oncology Report.. 31(6); 2467-2476.

Martin, A.G. 2007. Molecular Biology of Cervical Cancer. Clin. Transl. Oncol. 9: 347-354.

Morotomi-Yano, K., Akiyama, H., and Yano, K. 2011. Nanosecond Pulsed Electric Fields Activate MAPK Pathways in Human Cells. Biochem. Biophys. Res. Commun. 515: 99106.

Morotomi-Yano, K., Oyadomari, S., Akiyama, H., and Yano, K. 2012. Nanosecond Pulsed Electric Act as A Novel Cellular Stress That Induces Translational Suppression Accompanied by elF2a Phosphorylation and 4E-BP1 Dephosphorylation. Nanosecond Pulsed Electric Fields Activate MAPK Pathways in Human Cells. Biochem. Biophys. Res. Commun. 318: 1733-1744.

Nagahama, M., Shimomura, N., Nakagawa, A., Teranishi, K., Uto, Y., and Hori, H. 2013. In Vivo Experimental Study of Nanosecond Pulsed Electric Field Effects on Solid Tumors. IEEE Transactions on Dielectrics and Electrical Insulation. 20: 1266-1272. 


\section{Martina Kurnia Rohmah}

Pengaruh Variasi Jumlah Tembakan Nanosecond Pulsed Electric FIELDS (NsPEFs) Terhadap Ekspresi Gen Socs3 pada Sel Kanker Serviks Hela S3

Nuccitelli, R., Chen, X., Pakhomov, A.G., Baldwin, W.H., Sheikh, S., Pomicter, J.L., Ren, W., Osgood, C., Swanson, R.J., Kolb, F.F., Beebe, S.J., and Schoenbach, K.H. 2009. A New Pulsed Electric Field Therapy for Melanoma Disrupts the Tumor's Blood Supply and Causes Complete Remission without Recurrence. Int. J. Cancer. 125: 438-445.

Ren, W., and Beeb, S.J. 2011. An Apoptosis Targeted Stimulus With Nanosecond Pulsed Electric Fields (NsPEFs) in E4 Squamous Cell Carcinoma. Apoptosis. 16: 382-393.

Ren, Z., Chen, X., Cui, G., Yin, S., Chen, L., Jiang, J., $\mathrm{Hu}, \mathrm{Z} ., \mathrm{Xie}, \mathrm{H} ., \mathrm{Zheng}, \mathrm{S}$., and Zhou, L. 2013. Nanosecond Pulsed Electric Field Inhibits cancer Growth Followed by Alteration in Expression of NF-kB and Wnt/ $\beta$-catenin Signaling Molecules. PLOSone. 8: 1-12.

Rohmah, M.K., Lyrawati, D., Yano, K. Nanosecond Pulsed Electric Fields (nsPEFs) Induce Socs1 and Socs3. Jurnal Kedokteran Brawijaya. Vol 28 (3): 1-7.

Singh, N., Hussain, S., Suri, V., Bharadwaj, M., Das, B. C., Sobti, R.C. 2011. Aberrant Expression of Trancription Factors STAT -3 and STAT -5 and Their Epigenetic Control by SOCS-1 Gene: The STAT Signaling Crostalk in HPV Coupled Cervical Carcinogenesis, Proc. AACR 102nd Annu. Meet. Doi: 10.1158/15387445.AM2011-2719.

Sobti RC, Singh N, Hussain S, Suri V, Bharti AC, and Das BC. Overexpression of STAT3 in HPV-mediated Cervical Cancer in a North Indian Population. Mololecular and Biochemistry. 2009; 330(1-2): 193-199.

Sobti RC, Singh N, Hussain S, Suri V, Bharadwaj $\mathrm{M}$, and Das BC. Deregulation of STAT-5 Isoforms in the Development of $\mathrm{HPV}$ Mediated Cervical Carcinogenesis. Journal of Receptor and Signal Transductions. 2010; 30(3): 178-188.

Stacey, M., Stickley, J. Fox, P., Statler, V., Schoenbach, K.H., Beebe, S.J., and Buescher, S. 2003. Differential Effects in Cells Exposed to Ultra-Short, High Intensity Electric Fields: Cell Survival, DNA Damage, and Cell Cycle Analysis. Mutation Res. 542: 65-75.

Wu, S., Wang, Y., Guo, J., Chen, Q., Zhang, J., and Fang, J. 2014. Nanosecond Pulsed Electric fields as a Novel Drug Free Therapy for Breast Cancer: An In Vivo Study. Cancer Letter. 343: 268-274.

Zou, H., Gan, X.L., Linghu, L.J., Chen, C., Hu, L.N., and Zhang, Y. 2013. Intense Nanosecond Pulsed Electric Fields Promote Cancer Cell Apoptosis Through CentrosomeDependent Pathway Involving Reduced Level of PLK1. Eur. Rev. Med. Pharmacol. Sci. 17: 152-160. 